Martin D. Henry (ITQ, vol. 69/2, 2004, 188)

\title{
Christianity and the Enlightenment
}

It could be argued that the European Enlightenment of the seventeenth and eighteenth centuries is not merely a product of the Christian tradition, but is itself in a quite specific sense reminiscent of the original emergence of Christianity in the world of late antiquity. Just as Christianity, as a cultural entity, grew out of Judaism (a Judaism that had for some three centuries of course been exposed to various levels of contact with Hellenistic civilization), so, mutatis mutandis, the Enlightenment grew out of the European Christian tradition. Early Christianity had been an uneasy, even potentially volatile, synthesis of Jewish and Hellenistic components. And in time, this synthesis was to become the 'soul' of the initially ramshackle political entity that arose from the corpse of the Western Roman Empire in the wake of the barbarian invasions. Just how volatile the Christian tradition could be, the Enlightenment eventually revealed.

What is common, however, to the Enlightenment and Christianity is the fact that, for those involved in both movements, once the 'light' had dawned, there was no going back to a previous age or a more traditional world view. The only way to proceed was to go forward. Though, as we know from Paul, a return to Judaism remained a temptation, early Christians, on the whole, did not feel they could go back to the Judaism of their own past. Likewise, for the participants in the Enlightenment, there was no going back to a 'pre-critical' world.

Two further similarities are worth noting. Firstly, neither movement wished to make, or did in fact make, a total, revolutionary break with its past (witness the fact that the early Church did not reject the Hebrew scriptures, nor did the Enlightenment abandon the notion of 'the uniqueness and universality of truth' ${ }^{1}$ ). And secondly, the most committed participants in the new movements had to face the suspicion and often open hostility of members of the communities they sprang from (witness the persecution of the early Christians by certain elements in traditional Judaism, and the resistance to Enlightenment ideas by both Church and State in the West down to quite recent times).

1 Ernest Gellner, Postmodernism, Reason and Religion (London/New York: Routledge, 1992), 58. Gellner characterizes the faith of the Enlightenment thus: 'Rationalism was the continuation of exclusive monotheism by other means' (ibid.). 
But perhaps for Christianity the most interesting conclusion to draw from the parallel invoked, is the suspicion that, just as the emergence of Christianity did not mean the end of Judaism, nor does the emergence of the Enlightenment have to mean the end of Christianity. Rather, what the history of all three movements does appear to suggest, is that, while 'truth' keeps on the move, thereby keeping us on our intellectual toes, the historical communities in which ultimate and abidingly resistant elements of the human condition were originally identified and articulated, have continued to survive. What course the Christian Church should now try to plot so as to incorporate the demands of critical thinking less timorously than heretofore within its own sense of being the embodiment of a religion tied to certain specific historical events, is a question that theology may legitimately raise, but obviously cannot answer. 